\title{
VARIASI DIALEKTAL BAHASA TOMUAN (DIALECTAL VARIATION OF TOMUAN LANGUAGE)
}

\author{
Andi Indah Yulianti \\ Balai Bahasa Sulawesi Selatan \\ Jalan Sultan Alauddin Km. 7 Tala Salapang, Makassar \\ Posel: ndah_8082@yahoo.com
}

\begin{abstract}
Tomuan language is spoken by the people residing in East Kotawaringin and Lamandau district, Central Kalimantan. The problem to be answered in this research is to identify any variations of the language that appears on Tomuan language in Menthobi Raya and Bulik sub-district of Lamandau, Central Kalimantan. In general, this study aimed to identify the forms of dialectal variation that appears in the Tomuan language on those two districts. The theoretical benefits of this research expected is to provide an overview of how a variation of the language can be a differentiator for certain groups target. In addition, the practical benefits of this study, may be used as a strategic step in setting government policy politics of language and language preservation areas in Indonesia. Analysis of the data in this study is using two analytical methods, dialectometric method and lexicostatistics method sourced from the base of 200 Swades vocabulary and Culture Association Vocabulary (A, C, P, and R). The source data in this study is from local languages utterances made by people in the village of Lubuk Hiju, District Menthobi Raya, and the village of Guci in District of Bulik, Lamandau district, Central Kalimantan.
\end{abstract}

Key words: Tomuan language, dialectal variation, dialectometric, lexicostatistic.

Abstrak

Bahasa Tomuan dituturkan oleh masyarakat yang berada di kabupaten Kotawaringin Timur dan kabupaten Lamandau, Provinsi Kalimantan Tengah. Masalah yang ingin diungkapkan dalam penelitian ini adalah untuk mengindentifikasi bentuk variasi bahasa apa saja yang muncul pada bahasa Tomuan di kecamatan Menthobi Raya dan kecamatan Bulik di Kabupaten Lamandau, Provinsi Kalimantan Tengah. Secara umum penelitian ini bertujuan untuk mengidentifikasi bentuk variasi dialektal yang muncul pada bahasa Tomuan pada dua kecamatan tersebut. Manfaat teoritis dari penelitian ini diharapkan akan memberikan gambaran bagaimana sebuah variasi bahasa dapat menjadi pembeda bagi kelompok masyarakat tertentu. Di samping itu, manfaat praktis dari penelitian ini, agar dapat dijadikan langkah strategis kebijakan pemerintah dalam menetapkan politik bahasa dan pemertahanan bahasa daerah di Indonesia. Analisis data dalam penelitian ini menggunakan dua metode analisis, yaitu metode dialektometri dan leksikostatistik yang bersumber dari 200 Kosa Kata dasar Swades dan 200 Kosa Kata Budaya Dasar (A,C,P, dan R). Data yang diperlukan dalam penelitian ini berupa data kebahasaan yang bersumber dari tuturan bahasa-bahasa daerah yang dilakukan oleh masyarakat di Desa Lubuk Hiju, Kecamatan Menthobi Raya, dan Desa Guci di Kecamatan Bulik, kabupaten Lamandau, provinsi Kalimantan Tengah.

Kata Kunci: bahasa Tomuan, variasi dialektal, dialektometri, leksikostatistik 


\section{Pendahuluan}

Penelitian dialektologi di Kalimantan Tengah masih sangat kurang. Adapun penelitian dialektologi yang dianggap berharga adalah Barito Isolects of Borneo: A Classification Based on Comparative Reconstruction and Lexicostatistics (Hudson, 1967), Kajian Dialek Geografi Bahasa Dayak Ngaju Dialek Pulau Petak yang dilakukan Mihing (1977). Kemudian, Ngabut, dkk. (1995) mengkaji masalah Dialek Bahasa Daerah di Kabupaten Barito Selatan, dan Poerwadi (1993) dengan penelitian Perbandingan Bahasa-bahasa di Kalimantan Tengah: Studi Pengelompokan Bahasa. Berdasarkan kenyataan tersebut di atas, penelitian yang mengambil objek bahasa-bahasa daerah di wilayah Kabupaten Lamandau pun masih belum selesai dilakukan. Walaupun demikian, terdapat beberapa peneliti mencoba menggali beberapa bahasa yang terdapat di wilayah Kalimantan Tengah ini dari kajian yang berbeda. Poerwadi (1993) meneliti masalah Perbandingan Bahasa-bahasa di Kalimantan Tengah: Studi Pengelompokan Bahasa secara umum melalui bidang kajian linguistik historis komparatif, termasuk di dalamnya bahasa-bahasa di wilayah kabupaten
Seruyan, tetapi belum mencakup seluruh wilayah secara keseluruhan (terutama bagian hulu yang berbatasan dengan kabupaten maupun provinsi lainnya). Di samping itu, penelitian tentang situasi kebahasaan di Indonesia telah dilakukan oleh Pusat Bahasa dalam buku Bahasa dan Pemetaan Bahasa di Indonesia (2008) yang merupakan rujukan terakhir tentang situasi bahasa dan dialek di Indonesia.

Menurut Bahasa dan Pemetaan Bahasa di Indonesia terbitan Pusat Bahasa (2008), bahasa Tomuan dituturkan oleh masyarakat yang berada di Kotawaringin Timur dan kabupaten Lamandau, Provinsi Kalimantan Tengah. Bahasa ini terdiri atas dua dialek, yaitu dialek Tehang yang dituturkan di desa Tehang, kecamatan Parenggean dan desa Pundu, kecamatan Cempaga Hulu, dan dialek Nanga Bulik di Kecamatan Bulik. Presentase antardialek tersebut sebesar $73,05 \%$. Sementara itu, berdasarkan perhitungan dialektometri, isolek Tomuan merupakan sebuah bahasa dengan presentase perbedaan berkisar $81-97 \%$ jika dibandingkan dengan bahasa-bahasa lain yang ada di provinsi Kalimantan Tengah. Misalnya, presentase perbedaan antara bahasa Tomuan dan bahasa Dayak Ngaju sebesar $95 \%$. 
Berdasarkan paparan di atas, masalah yang ingin diungkapkan dalam penelitian ini adalah untuk mengindentifikasi bentuk variasi bahasa apa saja yang muncul pada bahasa Tomuan di kecamatan Menthobi Raya dan kecamatan Bulik di Kabupaten Lamandau, Provinsi Kalimantan Tengah. Secara umum, penelitian ini bertujuan untuk mengidentifikasi bentuk variasi dialektal yang muncul pada bahasa Tomuan di Kecamatan Menthobi Raya dan kecamatan Bulik di Kabupaten Lamandau, Provinsi Kalimantan Tengah.

Manfaat teoritis dari penelitian ini diharapkan akan memberikan gambaran bagaimana sebuah variasi bahasa dapat menjadi pembeda bagi kelompok masyarakat tertentu. Di samping itu, manfaat praktis dari penelitian ini, semoga dapat dijadikan langkah strategis kebijakan pemerintah dalam menetapkan politik bahasa dan pemertahanan bahasa daerah di Indonesia.

\section{Kerangka Teori}

Teori tentang perbandingan bahasa yang dianggap sesuai untuk penelitian ini adalah dialektologi diakronis. Kajian dialektologi diakronis digunakan untuk memperoleh status sebuah isolek sebagai dialek atau subdialek. Beberapa konsep dasar dari teori tersebut dipaparkan sebagai berikut.

Dialektologi dalam konsep Bynon (1977) dalam Mahsun (1995:9) mengungkapkan bahwa sebuah perubahan bunyi itu tidak memengaruhi kata-kata dalam leksikon sekaligus, tetapi satu per satu, sehingga pada waktu perubahan itu terjadi ada kata-kata tertentu lainnya yang tidak mengalami perubahan. Hal lain juga yang perlu diperhatikan adalah bahwa setiap kata dalam suatu bahasa memiliki sejarah sendiri-sendiri (lihat pula Gillieron dalam Mahsun, 1995:9). Dengan demikian, dialektologi sebagai ilmu tentang dialek atau cabang linguistik mengkaji perbedaan-perbedaan isolek dengan memperlakukan perbedaan tersebut secara utuh (Kridalaksana, 1984:39). Istilah dialek menurut Mahsun berkaitan dengan semacam bentuk isolek yang substandar dan berstatus rendah (1995:11). Konotasi negatif tersebut menurutnya dalam pandangan sosiolinguistis semata yang memperhitungkan penilaian penutur tentang keragaman isolek serta pemilihan sosial yang berkaitan dengan bahasa dan kelakuan berbahasa. Istilah tersebut juga sering dipertentangkan dengan istilah bahasa yang merujuk pada isolek yang telah dibakukan dan menjadi sumber 
rujukan penilaian isolek lain yang setingkat dengannya, tetapi belum dibakukan. Dengan kata lain, bahwa dialek dipandang merupakan penilaian hasil perbandingan dengan salah satu isolek yang dianggap lebih unggul (dalam Mahsun, 1995:12). Padahal dalam sudut pandang ilmu bahasa secara holistik bahwa dialek tidak serta merta sebagai sebuah isolek yang substandar dan berstatus rendah, melainkan dipandang sebagai sebuah isolek yang utuh dan digunakan sebagai varian dari isolek yang ada (Kridalaksana, 1993:42).

Berkaitan dengan realitas tersebut, Mahsun (1995:13) mengungkapkan bahwa dialektologi diakronis adalah suatu kajian tentang perbedaan-perbedaan isolek yang bersifat analitis sinkronis dengan penafsiran perbedaan-perbedaan isolek tersebut berdasarkan kajian yang bersifat historis atau diakronis. Dengan kata lain, dialektologi diakronis adalah kajian tentang "apa dan bagaimana" perbedaan isolek-isolek yang terdapat dalam satu bahasa.

Persoalan yang diketengahkan dalam kajian dialektologi diakronis secara segmental lebih banyak ditekankan pada perbedaan unsur-unsur kebahasaan. Untuk itu, deskripsi dari perbedaan variasi dialek-dialek (subdialek- subdialek) yang tersebar dalam wilayah penelitian menjadi inti dari persoalan perbedaan dimaksud. Perbedaan itu meliputi peerbedaan fonologi dan leksikon yang ditemukan berdasarkan evidensi dialektal dan subdialektal pada daerah pengamatan. Mahsun (2006:51) menyatakan contoh pengucapan bunyi bahasa Austronesia Purba (Protobahasa Austronesia) $*[\mathrm{~b}] / \#-$ sebagai bunyi $[\mathrm{w}]$ pada penutur bahasa Jawa tidaklah terjadi karena adanya keinginan yang menggebugebu dari para penuturnya untuk bangun pagi-pagi secara serentak mengucapkan bunyi [b] sebagai [w], melainkan ada seorang atau beberapa orang penutur yang dalam jangka waktu tertentu mengucapkan $*[b]$ sebagai $[\mathrm{w}]$, lalu kecendrungan ini menyebar pada penuturpenutur lainnya. Dengan demikian, setiap kajian dialektal (variasi bahasa) yang didasarkan pada pertimbangan perbedaan sinkronis haruslah secara serius mempertimbangkan mekanisme perubahan diakronis. Dalam pandangan ini, mengisyaratkan bahwa setiap variasi bahasa dapat dirunut pada sebuah asal yang merupakan bentuk purba dari varian-varian tersebut. Dengan demikian, dapat dikatakan bahwa bentuk-bentuk bahasa modern yang dapat dirunut kesatuasalannya itulah yang disebut 
dengan bentuk bahasa yang berkerabat (Mahsun, 2006:52).

$$
\text { Mahsun (1995:15) menyatakan }
$$
bahwa dialektologi sebagai cabang dari linguistik melingkupi kajian yang berpijak dari konsep-konsep yang dikembangkan linguistik. Konsep-konsep dimaksud bertalian dengan konsepkonsep yang digunakan dalam bidangbidang kajian linguistik (umum), seperti konsep fonem dan alofon untuk bidang fonologi, atau konsep fitur distingtif (distinctive feature) untuk fonologi generatif. Konsep-konsep tersebut terutama sangat bermanfaat dalam kerangka deskripsi perbedaan unsurunsur kebahasaan di antara daerah pengamatan dalam penelitian dan deskripsi ciri-ciri kebahasaan yang menjadi penanda atau pembeda antara dialek/subdialek yang satu dengan lainnya.

$$
\text { Aspek deskriptif yang }
$$

menyangkut perbedaan fonologi meliputi perubahan bunyi yang terjadi pada dialek dan subdialek yang diteliti. Perubahan bunyi tersebut ada berupa perubahan bunyi yang teratur dan sistematis yang dikenal sebagai korespondensi dan perubahan bunyi yang tidak teratur atau secara sporadis yang dikenal dengan variasi (Mahsun, 1995:28--29). Menurut Mahsun, korespondensi pada kaidah perubahan bunyi yang terjadi pada dua hal, yaitu secara linguistis yang mengakibatkan perubahan itu terjadi pada lingkungan linguistik tertentu, sedangkan secara geografis kaidah perubahan itu terjadi jika daerah sebaran leksemleksem yang menjadi realisasi perbedaan bunyi itu terjadi dalam daerah pengamatan yang sama. Namun, realisasi kaidah leksem-leksem tersebut dapat juga terjadi pada daerah pengamatan (beberapa makna tertentu) yang tidak sama. Hal ini dimungkinkan karena pengaruh antardaerah pengamatan dialek/subdialek atau karena proses peminjaman (borrowing).

\section{Metode Penelitan}

\subsection{Gambaran Umum Kabupaten Lamandau}

Kabupaten Lamandau terbentuk dari hasil pemekaran wilayah Kabupaten Kotawaringin Barat, berdasarkan UU nomor 5 Tahun 2002. Melalui proses yang sangat panjang dan rumit, Kabupaten Lamandau akhirnya dapat terbentuk dan berdiri sampai hari ini dengan ibu kota terletak di Nanga Bulik. (http://www.lamandaukab.go.id) 


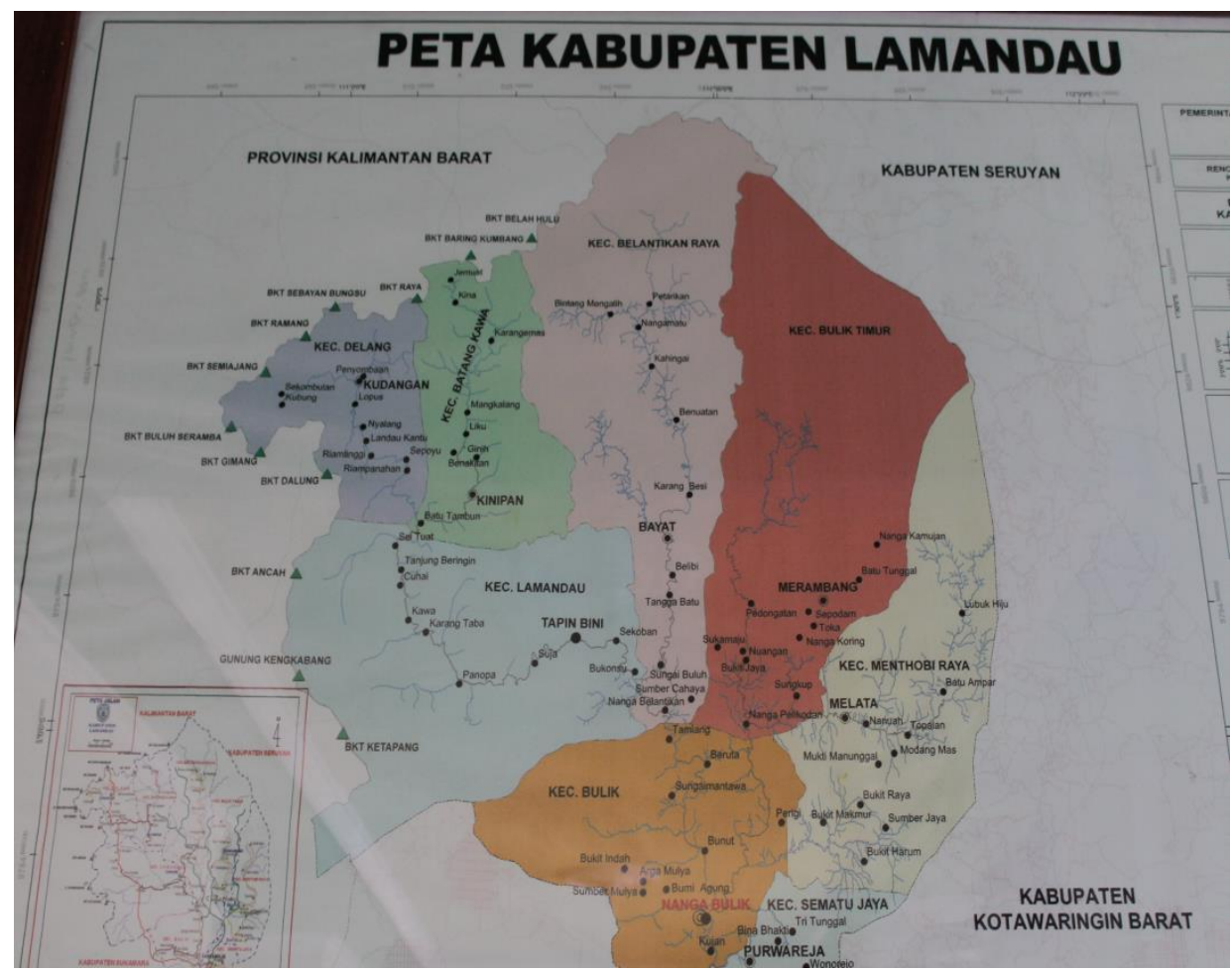

Nanga Bulik merupakan titik sentral yang dapat dijangkau, baik melalui jalur sungai maupun jalur darat antardesa di sekitarnya dan merupakan pintu gerbang perekonomian masyarakat dari Daerah Aliran Sungai (DAS) Lamandau, Bulik, Menthobi, Palikodan, Belantikan, Delang, dan Batangkawa. Posisi Nanga Bulik sangat strategis serta didukung oleh berbagai sumber daya alam yang berlimpah, baik hasil hutan, perkebunan, peternakan, pertambangan, serta flora dan fauna yang dapat dimanfaatkan sebagai sumber kehidupan dan kesejahteraan masyarakat dari ketujuh DAS yang berada di wilayah tersebut.

Wilayah utara kabupaten Lamandau berbatasan dengan Provinsi Kalimantan Barat serta sebagian dengan Kabupaten Kotawaringin Barat, sedangkan wilayah selatan berbatasan dengan Kabupaten Sukamara dan Kotawaringin Barat. Begitu pula wilayah barat, Kabupaten Lamandau berbatasan dengan provinsi Kalimantan Barat dan sebagian Kabupaten Sukamara, sedangkan wilayah timurnya berbatasan dengan Kabupaten Kotawaringin Barat.

Diketahui, luas wilayah Kabupaten Lamandau sekitar 6.414,00 $\mathrm{Km}^{2}$ dengan jumlah penduduk 71.788 jiwa. Wilayah administrasi Kabupaten Lamandau terdiri atas delapan kecamatan, yaitu Batangkawa, Belantikan Raya, 
Bulik, Bulik Timur, Delang, Lamandau, Menthobi Raya, dan Sematu Jaya. Di Kabupaten Lamandau, juga secara administratif terdapat tiga kelurahan, dan delapan puluh (80) desa (http://www.lamandaukab.go.id).

Dari beberapa kecamatan di atas, dipilih dua kecamatan sebagai daerah pengamatan, yaitu Kecamatan Menthobi Raya dan Kecamatan Bulik. Dasar pemilihan daerah pengamatan tersebut dengan merujuk pada wilayah tutur yang digunakan pada tiap-tiap bahasa yang akan dijadikan sebagai sampel penelitian. Dari tiap-tiap kecamatan, dipilih satu desa. Dua desa yang dijadikan daerah pengamatan merupakan wilayah tutur yang masih cenderung mengalami kurangnya kontak keluar. Dengan demikian, diharapkan sampel penelitian lebih valid. Di samping itu, penduduk asli tersebut tetap setia menggunakan bahasanya.

\subsection{Kecamatan Menthobi Raya}

Luas wilayah kecamatan Menthobi Raya 620,8 $\mathrm{Km}^{2}$. Wilayah administrasi Kecamatan Menthobi Raya terdiri atas sebelas (11) desa, antara lain Desa Bukit Harum, Sumber Jaya, Bukit Makmur, Bukit Raya, Mukti Manunggal, Modang Mas, Melata, Nanuah, Topalan, Batu Ampar, dan Lubuk Hiju.
Wilayah utara Kecamatan Menthobi Raya berbatasan dengan Kecamatan Bulik Timur, sedangkan wilayah selatan berbatasan dengan Kecamatan Sematu Jaya. Wilayah barat Kecamatan Menthobi Raya berbatasan dengan Kecamatan Bulik, sedangkan wilayah timurnya berbatasan dengan Kabupaten Kotawaringin Barat.

Diketahui, bahwa di Kecamatan Menthobi Raya ini, terdapat sebelas (11) desa. Dari kesebelas desa tersebut, dipilih Desa Lubuk Hiju sebagai daerah pengamatan. Dipilihnya Desa Lubuk Hiju sebagai daerah pengamatan karena merujuk pada wilayah tutur yang digunakan pada bahasa yang akan dijadikan sebagai sampel penelitian. Berdasarkan letak geografis, Desa Lubuk Hiju merupakan wilayah tutur yang masih cenderung mengalami kurangnya kontak keluar, baik antardesa, antarkecamatan, maupun dengan ibu kota kabupaten. Oleh karena itu, diharapkan sampel penelitian lebih sahih dan valid. Di samping itu, berdasarkan pengamatan, bahwa penduduk asli Desa Lubuk Hiju merupakan masyarakat yang sangat setia menggunakan bahasanya.

Penduduk Desa Lubuk Hiju sebanyak 680 orang, terdiri atas 215 kepala keluarga dengan 354 orang lelaki 
dan 326 orang perempuan. Dapat dikatakan, mata pencaharian penduduk desa ini $100 \%$ bertani. Pendidikan ratarata masyarakat yang mendiami desa Lubuk Hiju hanya sampai tingkat SD dan SMP. Di desa ini pun, sarana pendidikan sangat terbatas, yakni hanya terdapat sebuah Sekolah Dasar dan sebuah Sekolah Menengah Pertama.

Mayoritas penduduk desa Lubuk Hiju menganut agama Kristen Protestan $(80 \%)$ dan sisanya (20\%) menganut Hindu (Kaharingan). Jalur hubungan antardesa sangat terbatas (tidak lancar). Hal ini menyebabkan hubungan masyarakat desa dengan dunia luar (desa lain) juga terhambat. Masyarakat desa hanya mengandalkan prasarana hubungan transportasi pribadi, khususnya sepeda motor yang dapat digunakan untuk keperluan sehari-hari dan tidak ada prasarana angkutan umum, seperti halnya di perkotaan.

Situasi geografis desa Lubuk Hiju berada di pedalaman hutan Kalimantan dengan jalan berbukit, sehingga jika ingin sampai ke titik desa dari ibu kota Kabupaten Lamandau harus digunakan alat transportasi/kendaraan yang sesuai dengan medan tempuh yang sangat berat. Kondisi sangat terpencil dan jauhnya jarak desa Lubuk Hiju dengan ibu kota
Kabupaten Lamandau merupakan salah satu penyebab pembangunan berbagai sektor sangat tertinggal. Ini terbukti dengan tidak adanya jaringan listrik, telepon, dan air yang begitu vital bagi kehidupan masyarakat desa. Di desa ini, tidak ditemukan juga adanya kantor/balai desa, tempat untuk mencari informasi mengenai desa. Informasi mengenai situasi desa hanya mengandalkan seorang mantir/kepala suku yang dipercaya oleh seluruh masyarakat desa. Usia desa ini diperkirakan dibangun sekitar 50--100 tahun yang lalu.

\subsection{Kecamatan Bulik}

Luas wilayah kecamatan Bulik 665,55 $\mathrm{Km}^{2}$, sedangkan wilayah administrasi Kecamatan Bulik memiliki dua belas (12) desa, yakni Tamiang, Beruta, Sungai Mentawa, Bunut, Bukit Indah, Arga Mulya, Bumi Agung, Sumber Mulya, Kujan, Nanga Bulik, Perigi, dan Guci.

Kecamatan Bulik wilayah utara berbatasan dengan Kecamatan Belantikan Raya dan wilayah selatan berbatasan dengan Kabupaten Sukamara. Batas wilayah barat Kecamatan Bulik berbatasan dengan Kecamatan Lamandau, sedangkan wilayah timurnya berbatasan dengan Kecamatan Sematu Jaya dan sebagian Kecamatan Menthobi Raya.

Kecamatan Bulik memiliki dua belas desa (12) desa, dari kesemua desa 
tersebut, dipilih Desa Guci sebagai daerah pengamatan. Dipilihnya Desa Guci sebagai daerah pengamatan karena sesuai dengan wilayah tutur yang digunakan pada bahasa yang akan dijadikan sebagai sampel penelitian. Secara geografis, Desa Guci juga merupakan wilayah tutur yang masih cenderung mengalami kurangnya kontak keluar, baik antardesa, antarkecamatan, maupun dengan ibu kota kabupaten, meskipun jarak tempuh dari desa ke ibu kota kabupaten tidak terlalu jauh. Sehubungan dengan itu, diharapkan sampel penelitian yang didapat lebih sahih dan valid.

Masyarakat Desa Guci berjumlah 334 orang, yakni terdiri atas 96 kepala keluarga dengan 175 orang lelaki dan 159 orang perempuan. Mata pencaharian masyarakat desa ini dapat dikatakan $100 \%$ di bidang pertanian. Pendidikan masyarakat desa Guci 50\% hanya sampai tingkat SD, 25\% SMP, dan 25\% lagi sampai SMA. Di desa ini pun, sarana pendidikan sangat terbatas, tidak ada SMP atau SMA, tetapi hanya terdapat SD sebanyak tiga buah.

Mayoritas penduduk Desa Guci menganut agama Kristen Protestan (50\%), $\quad 30 \%$ menganut Hindu (Kaharingan), dan sisanya 20\% menganut agama Islam. Jalur hubungan antardesa dapat dikatakan lancar. Hal ini dikarenakan jarak tempuh antardesa tidak terlampau jauh dan waktu tempuh menuju ibu kota kabupaten pun dapat dijangkau hanya dengan kurang dari satu jam waktu perjalanan. Masyarakat Desa Guci pun hanya mengandalkan kendaraan pribadi, khususnya sepeda motor untuk keperluan transportasi sehari-hari dan untuk menuju desa ini juga tidak terdapat fasilitas angkutan umum, seperti angkutan kota atau yang lainnya.

Jika dilihat dari situasi geografis, Desa Guci berada di pedalaman dengan kondisi jalan dataran yang terjal, sempit, dan berliku. Jarak Desa Guci dengan ibu kota Kabupaten Lamandau, Nanga Bulik, tidak terlalu jauh, tetapi pembangunan beberapa sektor masih banyak tertinggal. Meskipun sudah memiliki fasilitas jaringan listrik, Desa Guci masih tampak terpencil. Di desa ini, terdapat kantor/balai desa yang sangat sederhana dan usia desa ini diperkirakan dibangun sekitar 50--100 tahun yang lalu.

Berdasarkan data desa, bahwa sebelah timur Desa Guci berbahasa Batu Hambawang (Desa Batu Hambawang), sebelah barat berbahasa Kotawaringin Barat, sebelah utara berbahasa Kujan, dan sebelah selatan desa ini berbahasa Kondang. 
3.4 Gambaran Umum Bahasa Tomuan

Dayak Tomun, Tomuan, atau Tamuan adalah etnis dayak yang bermukim di sepanjang sungai Lamandau dan sungai-sungai kecil di wilayah Kabupaten Lamandau. Tomun, Tomuan, atau Tamuan secara harfiah berarti "bertemu atau berjumpa". Orang-orang Dayak Tomuan sebenarnya jarang menggunakan bahasa Tomuan sebagai identitas diri mereka, tidak seperti orang Jawa yang menggunakan bahasa Jawa sebagai identitas diri. Orang-orang Dayak Tomuan tidak akan mengatakan bahwa mereka adalah orang Tomuan ketika ditanya, tetapi akan menjawab dengan nama desa atau sungai tempat mereka tinggal karena pada dasarnya nama Tomuan itu sendiri digunakan untuk menyatakan kumpulan-kumpulan masyarakat di wilayah Lamandau yang memiliki beragam bahasa dan dialek (www.http://oncik.blogspot.com/2012/07/ dayak-tomun.html).

Uniknya masyarakat yang berbeda bahasa di daerah Lamandau masih dapat mengerti bahasa mereka satu sama lain. Itulah sebabnya bahasa mereka disebut bahasa Tomun/Tomuan, karena ketika bertemu dan berkomunikasi dengan bahasa yang berbeda, tetapi tetap memahami satu sama lain.
Bahasa yang digunakan masyakarat Tomun/Tamuan biasanya disebut sebagai bahasa Dayak Tomuan (Pusat Bahasa, 2008, mengidentifikasi bahasa yang digunakan di wilayah masyarakat Dayak Tomuan ini sebagai bahasa Tamuan dialek Nanga Bulik). Bahasa yang digunakan oleh masyarakat Dayak Tomuan ini sangat mirip satu sama lain. Yang menjadi pembeda hanyalah pengucapan antar wilayah. Contohnya:

- Honak ka muna kula wa? (wilayah Batang Kawa)

- Hondak ka muno kulo? (wilayah Delang)

- Hondak ka mona ikam? (wilayah Bulik)

Contoh lainnya dilihat dari penekanan kata.

- Malapm (wilayah Batang Kawa)

- Malap (wilayah Tapin Bini)

- Bujakng (wilayah Batang Kawa)

- Bujang (wilayah Tapin Bini)

Bahasa Dayak Tomuan juga dipahami oleh masyarakat Dayak Arut dan masyarakat di Kabupaten Pangkalan Bun karena kemiripan bahasanya. Bahasa Dayak Tomuan juga memiliki kekerabatan dengan bahasa-bahasa Dayak di Kalimantan Barat, terutama pada daerah yang berbatasan langsung. Hal ini yang menjadi alasan banyaknya orang Dayak Tomuan yang merantau ke Provinsi Kalimantan Barat. 
Berdasarkan jenis data, yang ingin dicari dalam penelitian ini menyangkut data-data kebahasan yang bersifat empirik. Oleh karena itu, diperlukan metode-metode yang relevan. Dalam hal ini, yang akan digunakan adalah metode cakap, dengan teknik dasar berupa teknik pancing dan teknik lanjutan berupa cakap semuka (CS), cakap taksemuka (CTS), dan rekam-catat. Teknik-teknik tersebut tentu saja akan tetap berpegang pada instrumen yang sudah disiapkan (dalam hal ini Daftar Tanyaan Swades) untuk mempermudah proses penjaringan data dan untuk menghindari bias pertanyaan. Metode cakap semuka yang dimaksud adalah bahwa peneliti langsung terjun ke lapangan untuk mewawancarai informan (Sudaryanto, 1986:93). Informan yang diperlukan dalam penelitian ini adalah penutur bahasa daerah yang menjadi subjek penelitian, sehingga diperoleh data yang asli dan akurat.

Analisis data dalam penelitian ini menggunakan dua metode analisis, yaitu metode dialektometri dan leksikostatistik yang bersumber dari 200 Kosa Kata dasar Swades dan 200 Kosa Kata Budaya Dasar (A,C,P, dan R).

Data yang diperlukan dalam penelitian ini berupa data kebahasaan yang bersumber dari tuturan bahasa- bahasa daerah yang dilakukan oleh masyarakat di Desa Lubuk Hiju, Kecamatan Menthobi Raya, dan Desa Guci di Kecamatan Bulik, Kabupaten Lamandau. Kedua kecamatan ini dipilih sebagai daerah pengamatan (DP) dengan asumsi bahwa kedua wilayah tersebut memiliki bahasa dengan keunikan masing-masing dan berada di wilayah paling hulu Kabupaten Lamandau (Desa Lubuk Hiju, Kecamatan Menthobi Raya), sedangkan Desa Guci di Kecamatan Bulik merupakan berada di wilayah paling hilir Kabupaten Lamandau. Pemilihan sumber data ini merupakan langkah lanjutan dari penelitian terdahulu yang dikumpulkan oleh Tim Penelitian Kekerabatan dan Pemetaan Bahasa-Bahasa sebelumnya.

Penjaringan data bahasa-bahasa daerah dari kedua daerah pengamatan tersebut diperlukan masing-masing tiga (3) orang informan yang memenuhi syarat seperti yang disarankan Mahsun (1995:106) sebagai berikut.

1) Berjenis kelamin pria atau wanita;

2) Berusia 25-65 tahun (tidak pikun);

3) Orang tua, istri, atau suami informan lahir dan dibesarkan di desa itu serta jarang atau tidak pernah meninggalkan desanya;

4) Berpendidikan maksimal tamat pendidikan dasar (SD--SLTP); 
5) Berstatus sosial menengah (tidak rendah atau tinggi) dengan harapan tidak terlalu tinggi mobilitasnya;

6) Pekerjaanya bertani atau buruh;

7) Memiliki kebanggaan terhadap isolek dan masyarakat isoleknya;

8) Dapat berbahasa Indonesia; dan

9) Sehat jasmani dan rohani. Sehat jasmani maksudnya tidak cacat berbahasa dan memiliki pendengarran yang tajam untuk menangkap pertanyaan-pertanyaan dengan tepat; sedangkan sehat rohani maksudnya tidak gila atau pikun. (bandingkan dengan Samarin, 1988:55--57).
Selain itu, diperlukan data pendukung sebagai bahan pembanding, yaitu bersumber dari data kebahasaan yang telah tersedia berdasarkan hasil penelitian bahasa-bahasa daerah pada tahap sebelumnya.

\section{Pembahasan}

\subsection{Deskripsi Perbedaan Unsur-Unsur}

\section{Kebahasaan}

Deskripsi perbedaan unsur-unsur kebahasaan akan ditampilkan dalam bentuk peta verbal yang berupa tabulasi tahap I dan tahap II berikut ini.

Tabel 1.

Deskripsi Perbedaan Unsur-Unsur Kebahasaan

\begin{tabular}{|c|c|c|c|}
\hline & & BULASI DATA TAHAP & \\
\hline & IDENTIF & IARIAN DAN DAERAH & EBARANNYA \\
\hline I. KC & SA KATA DAS & & \\
\hline No. & GLOS & BENTUK REALISASI & $\begin{array}{c}\text { DAERAH } \\
\text { PENGAMATAN } \\
\end{array}$ \\
\hline 1 & Abu & habu: & 87 (Lubuk Hiju) \\
\hline & & Habuq & 88 (Guci) \\
\hline & & Habu & 15 (Nanga Bulik) \\
\hline 2 & Air & a.ray & 87 \\
\hline & & Aray & 88,15 \\
\hline 3 & Akar & aka.r & 87 \\
\hline & & Urat & 88 \\
\hline & & Akar & 15 \\
\hline 4 & Alir & ha nu\#n & 87 \\
\hline
\end{tabular}




\begin{tabular}{|l|l|l|l|} 
& & Alir & 88 \\
\hline & & hayuG & 15 \\
\hline 5 & dst & Dst & Dst \\
\hline
\end{tabular}

Prosedur kerja pada tabulasi dari 200 kosakat dasar Swades. tahap I adalah mengumpulkan kata-kata

Tabel 2.

Tabulasi Tahap II

Identifikasi Varian dan Daerah Sebarannya

Perbedaan Fonologi

Perbedaan yang berupa Variasi bunyi

\section{Kosa Kata Dasar}

\begin{tabular}{|c|c|c|c|}
\hline No. & KODE GLOS & BENTUK REALISASI & $\begin{array}{l}\text { DAERAH } \\
\text { PENGAMATAN }\end{array}$ \\
\hline \multirow[t]{12}{*}{1} & I. 10. apung(me) & 1. $b \sim \varnothing /-\# \mathrm{VK}$ & \\
\hline & & timbu:.1 & 87 \\
\hline & & Timbul & 88 \\
\hline & & Timul & 15 \\
\hline & & 2. $\mathrm{u}: \sim \mathrm{u} /=\# \mathrm{~K}$ & \\
\hline & & timbu:.1 & 87 \\
\hline & & Timbul & 88 \\
\hline & & Timul & 15 \\
\hline & & 3. .1 1/-\# & \\
\hline & & timbu:.1 & 87 \\
\hline & & Timbul & 88 \\
\hline & & Timul & 15 \\
\hline \multirow[t]{8}{*}{2} & I. 13. Ayah & 1. a) $0 \sim \mathrm{U} / \#-$ & \\
\hline & & ompa\&iq & 87 \\
\hline & & Umpay & 15 \\
\hline & & b) bapaq & 88 \\
\hline & & 2. a) iq $\sim / / \#$ & \\
\hline & & ompa\&iq & 87 \\
\hline & & Umpay & 15 \\
\hline & & b) bapaq & 88 \\
\hline \multirow[t]{2}{*}{3} & I. 16. Bakar & 1. $u \sim U / \# K-$ & \\
\hline & & tutu $=\mathrm{G}$ & 87 \\
\hline
\end{tabular}




\begin{tabular}{|c|c|c|c|}
\hline & & Tunu & 88 \\
\hline & & tUnU & 15 \\
\hline & & 2. $\mathbf{t} \sim \mathrm{n} / \# \mathrm{KV}$ - & \\
\hline & & tutu $=\mathrm{G}$ & 87 \\
\hline & & Tunu & 88 \\
\hline & & $\mathrm{tUnU}$ & 15 \\
\hline & & 3. $\mathbf{U} \sim \mathrm{U} /$-\#K & \\
\hline & & tutu $=\mathrm{G}$ & 87 \\
\hline & & Tunu & 88 \\
\hline & & $\mathrm{tUnU}$ & 15 \\
\hline & & 4. $=\mathrm{G} \sim \varnothing /-\#$ & \\
\hline & & tutu $=\mathrm{G}$ & 87 \\
\hline & & Tunu & 88 \\
\hline & & tUnU & 15 \\
\hline 4 & I. 17. Balik & 1. a) $. \mathrm{I} \sim \mathrm{l} / \mathrm{V}-\mathrm{V}$ & \\
\hline & & ba.IIq & 87 \\
\hline & & Balik & 88 \\
\hline & & b) dikulay & 15 \\
\hline & & 2. I $\sim \mathrm{i} / \mathrm{K}-\mathrm{K}$ & \\
\hline & & ba.lIq & 87 \\
\hline & & Balik & 88 \\
\hline & & b) dikulay & 15 \\
\hline 5 & I. 20. Baru & 1. ba $/ \#-$ & \\
\hline & & baha.ru: & 87 \\
\hline & & Baharu & 88 \\
\hline & & Horu & 15 \\
\hline & & 2. ha ho/\#KV- & \\
\hline & & baha.ru: & 87 \\
\hline & & Baharu & 88 \\
\hline & & Horu & 15 \\
\hline & & 3. $. r \sim r / V-V$ & \\
\hline & & baha.ru: & 87 \\
\hline & & Baharu & 88 \\
\hline & & Horu & 15 \\
\hline & & 4. $\mathrm{u}: \sim \mathrm{u} /-\#$ & \\
\hline & & baha.ru: & 87 \\
\hline & & Baharu & 88 \\
\hline & & Horu & 15 \\
\hline dst. & dst. & dst. & dst. \\
\hline
\end{tabular}


Prosedur kerja pada tabulasi tahap II adalah menetapkan kosakata yang berkerabat (pengaidahan).

Variasi dialek pada bahasa Tomuan merupakan variasi yang umum ditemukan di Kabupaten Lamandau. Hal ini menandakan bahwa bahasa Tomuan dituturkan oleh masyarakat hampir di semua aliran sungai di Kabupaten Lamandau, Kalimantan Tengah. Variasi tersebut dapat dilihat pada variasi fonem konsonan. Variasi fonemis pada dialek-

\section{Kosa Kata Budaya Dasar}

\section{Bagian Tubuh}

dialek yang menuturkan bahasa Tomuan di wilayah DP 87, desa Lubuk Hiju dicirikan oleh bunyi-bunyi konsonan /r/ retrofleks, /tn/ prehomorganik, dan /pm/ prenasal, /kng/ prehomorganik. Hal tersebut dapat dilihat pada glos 'akar', ombutn', 'binatakng', dan 'dalapm'. Terdapat juga peluluhan konsonan /b/ pada DP 15 desa Bulik 'timul', sedangkan di DP 87, desa Lubuk Hiju 'timbu:l', dan DP 88, desa Guci 'timbul'.

\begin{tabular}{|c|c|c|c|}
\hline No. & KODE GLOS & $\begin{array}{c}\text { BENTUK } \\
\text { REALISASI }\end{array}$ & $\begin{array}{l}\text { DAERAH } \\
\text { PENGAMATAN }\end{array}$ \\
\hline \multirow[t]{4}{*}{1} & $\begin{array}{l}\text { II. A. 202. bagian kuku yang } \\
\text { putih }\end{array}$ & $: \sim q /-\#$ & \\
\hline & & konu $=\mathrm{G}$ silu: & 87 \\
\hline & & kEmbaG siluq & 88 \\
\hline & & Kuku & 15 \\
\hline \multirow[t]{8}{*}{2} & II. A. 203. Bahu & a o/\#k- & \\
\hline & & bahu: & 87 \\
\hline & & bohu: & 88 \\
\hline & & Bahu & 15 \\
\hline & & $\mathbf{u}: \sim \mathbf{u} /-\#$ & \\
\hline & & bahu: & 87 \\
\hline & & bohu: & 88 \\
\hline & & Bahu & 15 \\
\hline \multirow[t]{3}{*}{3} & II. A. 211. Geraham & a $\sim \mathrm{e} \sim 0 / \# K-$ & \\
\hline & & ga.roha\$m & 87 \\
\hline & & Geraham & 88 \\
\hline
\end{tabular}




\begin{tabular}{|c|c|c|c|}
\hline & & gOrOhap & 15 \\
\hline & & $. \mathbf{r} \sim \mathbf{r} / \# \mathbf{K V}-$ & \\
\hline & & ga.roha\$m & 87 \\
\hline & & Geraham & 88 \\
\hline & & gOrOhap & 15 \\
\hline & & o a a O/K-K & \\
\hline & & ga.roha\$m & 87 \\
\hline & & Geraham & 88 \\
\hline & & gOrOhap & 15 \\
\hline & & $\$ \mathbf{m} \sim \mathbf{m} \sim \mathbf{p} / \#$ & \\
\hline & & ga.roha $\$ \mathrm{~m}$ & 87 \\
\hline & & Geraham & 88 \\
\hline & & gOrOhap & 15 \\
\hline & & & \\
\hline 4 & II. A. 221. Kelingking & 1. $\mathrm{e} \sim \mathrm{a} / \mathrm{K}-\mathrm{K}$ & \\
\hline & & kelinci $=\mathrm{G}$ & 87 \\
\hline & & kelinciG & 88 \\
\hline & & kalinciG & 15 \\
\hline & & 2. $=G \sim G / \#$ & \\
\hline & & kelinci $=\mathrm{G}$ & 87 \\
\hline & & jari kelinciG & 88 \\
\hline & & kalinciG & 15 \\
\hline 5 & II. A. 224. Keringat & o //K-K & \\
\hline & & Poluh & 87,88 \\
\hline & & plluh & 15 \\
\hline dst. & dst. & dst. & dst. \\
\hline
\end{tabular}

\section{Sistem Kekerabatan}

\begin{tabular}{|c|l|l|l|}
\hline No. & \multicolumn{1}{|c|}{ KODE GLOS } & \multicolumn{1}{c|}{$\begin{array}{c}\text { BENTUK } \\
\text { REALISASI }\end{array}$} & $\begin{array}{l}\text { DAERAH } \\
\text { PENGAMATAN }\end{array}$ \\
\hline 1 & $\begin{array}{l}\text { II. C. } 264 \text {. abang/kakak dari } \\
\text { istri }\end{array}$ & y $\sim$ /-\# & \\
\hline & & Kakay & 87,15 \\
\hline & & kakaq ipar & 88 \\
\hline & & & \\
\hline 2 & $\begin{array}{l}\text { II. C. } 270 . \text { adik laki-laki } \\
\text { ayah/ibu }\end{array}$ & maq $\varnothing / \#-~$ & \\
\hline & & Maqunsu & 87 \\
\hline
\end{tabular}




\begin{tabular}{|c|c|c|c|}
\hline & & Busuq & 88 \\
\hline & & unsu oGah & 15 \\
\hline & & $\mathbf{u} \sim \mathbf{b u} /-\# \mathbf{V K}$ & \\
\hline & & Maqunsu & 87 \\
\hline & & Busuq & 88 \\
\hline & & unsu oGah & 15 \\
\hline & & n Ø/-\#KV & \\
\hline & & Maqunsu & 87 \\
\hline & & Busuq & 88 \\
\hline & & unsu oGah & 15 \\
\hline & & Ø q//\# & \\
\hline & & Maqunsu & 87 \\
\hline & & Busuq & 88 \\
\hline & & unsu oGah & 15 \\
\hline 3 & $\begin{array}{l}\text { II. C. } 271 \text {. adik perempuan } \\
\text { ayah/ibu }\end{array}$ & un $\sim \mathbf{b u} / \#-$ & \\
\hline & & iyaq unsu & 87 \\
\hline & & Busuq & 88 \\
\hline & & unsu (oGah) & 15 \\
\hline & & q Ø/=\# & \\
\hline & & iyaq unsu & 87 \\
\hline & & Busuq & 88 \\
\hline & & unsu (oGah) & 15 \\
\hline 4 & II. C. 284. Menantu & Ø me/\#- & \\
\hline & & nantu: & 87 \\
\hline & & Nantu & 15 \\
\hline & & Menantu & 88 \\
\hline & & $\mathrm{u}: \sim \mathrm{u} /=\#$ & \\
\hline & & nantu: & 87 \\
\hline & & Nantu & 15 \\
\hline & & Menantu & 88 \\
\hline 5 & II. C. 285. Mertua & a: a/-\# & \\
\hline & & mantuha: & 87 \\
\hline & & Mantuha & 15 \\
\hline & & mentuho: & 88 \\
\hline & & ma me/\#- & \\
\hline & & mantuha: & 87 \\
\hline & & Mantuha & 15 \\
\hline
\end{tabular}




\begin{tabular}{|l|l|l|l|} 
& & mentuho: & 88 \\
\hline & & a: o:/-\# & \\
\hline & & mantuha: & 87 \\
\hline & & Mantuha & 15 \\
\hline & & mentuho: & 88 \\
\hline dst. & dst. & dst. & dst. \\
\hline
\end{tabular}

\section{Gerak dan Kerja}

\begin{tabular}{|c|c|c|c|}
\hline No. & KODE GLOS & $\begin{array}{c}\text { BENTUK } \\
\text { REALISASI }\end{array}$ & $\begin{array}{l}\text { DAERAH } \\
\text { PENGAMATAN }\end{array}$ \\
\hline \multirow[t]{12}{*}{1} & II. P. 914. Ambil & G $\sim$ Ø/\#- & \\
\hline & & Gamiq & 87 \\
\hline & & Ambiq & 88 \\
\hline & & Ami & 15 \\
\hline & & $\emptyset \sim \mathbf{b} / \# \mathbf{v k}$ & \\
\hline & & Gamiq & 87 \\
\hline & & Ambiq & 88 \\
\hline & & Ami & 15 \\
\hline & & q Ø/-\# & \\
\hline & & Gamiq & 87 \\
\hline & & Ambiq & 88 \\
\hline & & Ami & 15 \\
\hline \multirow[t]{8}{*}{2} & II. P. 918. Baca & a o a:/-\# & \\
\hline & & Baca & 15 \\
\hline & & Baco & 88 \\
\hline & & maca: & 87 \\
\hline & & $\mathbf{m} \sim \mathbf{b} / \#-$ & \\
\hline & & Baca & 15 \\
\hline & & Baco & 88 \\
\hline & & maca: & 87 \\
\hline \multirow[t]{6}{*}{3} & II. P. 925. Buka & $\mathbf{m} \sim \mathbf{b} / \#-$ & \\
\hline & & Mukaq & 87 \\
\hline & & Buka & 88,15 \\
\hline & & q Ø//\# & \\
\hline & & Mukaq & 87 \\
\hline & & Buka & 88,15 \\
\hline
\end{tabular}




\begin{tabular}{|c|c|c|c|}
\hline 4 & II. P. 931. Gantung & G $\sim \mathbf{g} / \#-$ & \\
\hline & & Gantu $=\mathrm{G}$ & 87 \\
\hline & & gantuG & 88 \\
\hline & & gantu $=\mathrm{G}$ & 15 \\
\hline & & $=\mathbf{G} \sim \mathrm{G} / \mathrm{- \#}$ & \\
\hline & & Gantu $=\mathrm{G}$ & 87 \\
\hline & & gantuG & 88 \\
\hline & & gantu $=\mathrm{G}$ & 15 \\
\hline \multirow[t]{16}{*}{5} & II. P. 933. henti (ber) & ba be/\#- & \\
\hline & & batoGaq & 87 \\
\hline & & batOGa & 15 \\
\hline & & betoGgaq & 88 \\
\hline & & O o/K-K & \\
\hline & & batoGaq & 87 \\
\hline & & batOGa & 15 \\
\hline & & betoGgaq & 88 \\
\hline & & Ø g/-kv\# & \\
\hline & & batoGaq & 87 \\
\hline & & batOGa & 15 \\
\hline & & betoGgaq & 88 \\
\hline & & q Ø/-\# & \\
\hline & & batoGaq & 87 \\
\hline & & batOGa & 15 \\
\hline & & betoGgaq & 88 \\
\hline dst. & dst. & dst. & dst. \\
\hline
\end{tabular}

Kata Tugas

\begin{tabular}{|c|l|l|l|}
\hline No. & \multicolumn{1}{|c|}{ KODE GLOS } & \multicolumn{1}{c|}{$\begin{array}{c}\text { BENTUK } \\
\text { REALISASI }\end{array}$} & $\begin{array}{l}\text { DAERAH } \\
\text { PENGAMATAN }\end{array}$ \\
\hline 1 & II. R. 1066. Belum & o $\mathbf{O} / \#$ K- & \\
\hline & & bolu\$m & 87 \\
\hline & & Bolum & 88 \\
\hline & & bOlu $\$ \mathrm{~m}$ & 15 \\
\hline & & $\mathbf{\$ m} \sim \mathbf{m} /$-\# & \\
\hline & & bolu\$m & 87 \\
\hline & & bOlu $\$ \mathrm{~m}$ & 15 \\
\hline 2 & II. R. 1067. besok (sesudah & Bolum & 88 \\
\hline
\end{tabular}




\begin{tabular}{|c|c|c|c|}
\hline & hari ini) & & \\
\hline & & Nobuq & 87 \\
\hline & & Hobuq & 88 \\
\hline & & Habu & 15 \\
\hline & & o a/\#K- & \\
\hline & & Nobuq & 87 \\
\hline & & Hobuq & 88 \\
\hline & & Habu & 15 \\
\hline & & $\mathbf{q} \sim$ Ø/-\# & \\
\hline & & Nobuq & 87 \\
\hline & & Hobuq & 88 \\
\hline & & Habu & 15 \\
\hline 3 & II. R. 1069. Dari & o u/\#K- & \\
\hline & & Mola & 15 \\
\hline & & mula: & 87 \\
\hline & & Dari & 88 \\
\hline & & a a:/-\# & \\
\hline & & Mola & 15 \\
\hline & & mula: & 87 \\
\hline & & Dari & 88 \\
\hline 4 & II. R. 1075. Ke & a a:- E/-\# & \\
\hline & & $\mathrm{Ka}$ & 15 \\
\hline & & ka: & 87 \\
\hline & & $\mathrm{kE}$ & 88 \\
\hline 5 & $\begin{array}{l}\text { II. R. 1076. kemarin (sebelum } \\
\text { hari ini) }\end{array}$ & $\mathbf{a} \sim \mathbf{e} \sim \mathbf{O} / \# \mathbf{K}-$ & \\
\hline & & kama.ri: & 87 \\
\hline & & Kemaya & 88 \\
\hline & & kOmay & 15 \\
\hline & & $. . \mathrm{r} \sim \mathrm{y} / \mathrm{V}-\mathrm{V}$ & \\
\hline & & kama.ri: & 87 \\
\hline & & Kemaya & 88 \\
\hline & & kOmay & 15 \\
\hline & & i: $\sim \mathbf{a} \sim \emptyset /-\#$ & \\
\hline & & kama.ri: & 87 \\
\hline & & Kemaya & 88 \\
\hline & & kOmay & 15 \\
\hline dst. & dst. & dst. & dst. \\
\hline
\end{tabular}




\section{TABULASI TAHAP II}

\section{PERBEDAAN LEKSIKON}

\section{Kosakata Dasar}

\begin{tabular}{|c|l|l|l|}
\hline No. & \multicolumn{1}{|c|}{ GLOS } & \multicolumn{1}{c|}{$\begin{array}{c}\text { BENTUK } \\
\text { REALISASI }\end{array}$} & $\begin{array}{l}\text { DAERAH } \\
\text { PENGAMATAN }\end{array}$ \\
\hline 1 & I. 14. Bagaimana & yawapa: & 87 \\
\hline & & Hibo & 88 \\
\hline & & Ubaqapa & 15 \\
\hline & & & \\
\hline 2 & I. 15. Baik & ba\&iq & 87 \\
\hline & & sEgaq & 88 \\
\hline & & jaGa & 15 \\
\hline & & & \\
\hline 3 & I. 30. Beri & o nu:qu & 87 \\
\hline & & bori: & 88 \\
\hline & & kOyU & 15 \\
\hline & & & \\
\hline 4 & I. 111. kelahi (ber) & batoki: & 87 \\
\hline & & Bekelohi & 88 \\
\hline & & bapOrap & 15 \\
\hline & & & \\
\hline 5 & I. 152. Pegang & hinti=G & 87 \\
\hline & & pigaG & 88 \\
\hline & & IGkuh & 15 \\
\hline & & & \\
\hline
\end{tabular}

Dari tabel di atas, dapat dilihat bahwa terdapat 5 glos yang berbeda penyebutannya pada setiap DP, yaitu II. Kosakata Budaya Dasar pada glos I.14. 'bagaimana', I.15 'baik', I.30. 'beri', I.111.'kelahi' dan I. 152 'pegang'.

\begin{tabular}{|c|c|c|c|}
\hline No. & KODE GLOS & $\begin{array}{c}\text { BENTUK } \\
\text { REALISASI }\end{array}$ & $\begin{array}{l}\text { DAERAH } \\
\text { PENGAMATAN }\end{array}$ \\
\hline \multicolumn{4}{|c|}{ A. Bagian Tubuh } \\
\hline \multirow[t]{3}{*}{1} & II. A. 209. Dagu & ra:G & 87 \\
\hline & & Jaguq & 88 \\
\hline & & kaGkapm & 15 \\
\hline
\end{tabular}




\begin{tabular}{|c|l|l|l|} 
& & & \\
\hline & & & \\
\hline 2 & $\begin{array}{l}\text { II. A. 213. gigi yang } \\
\text { bertumpuk }\end{array}$ & telaGkup & 87 \\
\hline & & gigi bEsalip & 88 \\
\hline & & gigi batumpa & 15 \\
\hline & & & \\
\hline & $\begin{array}{l}\text { II A. 214. gigi yang } \\
\text { menonjol }\end{array}$ & tu nay & 87 \\
\hline & & juGaG & 88 \\
\hline & & gigi tunjay & 15 \\
\hline & & & \\
\hline 4 & II A. 216. ibu jari & tu nu:q inu:q & 87 \\
\hline & & ibu jari & 88 \\
\hline & & tu¥u unay & 15 \\
\hline & & & \\
\hline 5 & II A. 218. Jari & tu nu:q & 87 \\
\hline & & jari: & 88 \\
\hline & & tu¥u inay & 15 \\
\hline dst. & dst. & dst. & dst. \\
\hline
\end{tabular}

TABULASI TAHAP II

GLOS YANG REALISASINYA SAMA

\begin{tabular}{|c|c|c|c|}
\hline No. & KODE GLOS & BENTUK REALISASI & $\begin{array}{l}\text { DAERAH } \\
\text { PENGAMATAN }\end{array}$ \\
\hline \multicolumn{4}{|c|}{ Kosakata Dasar } \\
\hline 1 & I 11. Asap & Asap & $87,88,15$ \\
\hline 2 & I 21. Basah & Basah & $87,88,15$ \\
\hline 3 & I 36. Buah & bu+ah & $87,88,15$ \\
\hline 4 & I 40. Bunuh & Bunuh & $87,88,15$ \\
\hline 5 & I 83. Hidup & Hidup & $87,88,15$ \\
\hline 6 & I 84. Hijau & Hijaw & $87,88,15$ \\
\hline 7 & I 100. Jatuh & jatu: & $87,88,15$ \\
\hline 8 & I 117. Kulit & Kulit & $87,88,15$ \\
\hline 9 & I 122. Laut & la+ut & $87,88,15$ \\
\hline 10 & I 128. Lidah & Dilah & $87,88,15$ \\
\hline 11 & I 131. Ludah & Lujah & $87,88,15$ \\
\hline
\end{tabular}




\begin{tabular}{|c|l|l|l|}
\hline 12 & I 134. Main & ma\&in & $87,88,15$ \\
\hline 13 & I 161. Pusar & Pusat & $87,88,15$ \\
\hline 14 & I 167. Sayap & Sayap & $87,88,15$ \\
\hline 15 & I 174. Sungai & suGay & $87,88,15$ \\
\hline 16 & I 180. Tanah & Tanah & $87,88,15$ \\
\hline 17 & I 195. Tongkat & tuGkat & $87,88,15$ \\
\hline 18 & I 198. Tumpul & Tumpul & $87,88,15$ \\
\hline Kosakata Budaya Dasar & \multicolumn{2}{|l}{} \\
\hline 19 & II A.222. kemaluan laki- & \multicolumn{2}{|l|}{} \\
\hline & laki & Butuh & $87,88,15$ \\
\hline 20 & II P. 927. Pergi & hiGkas & $87,88,15$ \\
\hline 21 & II P. 978. Putus & Putus & $87,88,15$ \\
\hline 22 & II P. 993. tangis (me) & naGis & $87,88,15$ \\
\hline 23 & II P. 996. Telungkup & tiGkap & $87,88,15$ \\
\hline 24 & II R. 1088. tiba-tiba & Tibatiba & \multicolumn{2}{l|}{} \\
\hline
\end{tabular}

\subsection{Perhitungan Secara Dialektometri}

Hasil analisis data akan Hasil Penghitungan Dialekditampilkan sesuai langkah-langkah tometri Kelompok DP Pemakai Bahasa yang dipaparkan di atas. Untuk jelasnya, secara sistematis dapat dilihat di daerah Nanga Bulik, Lubuk Hiju, dan sebagai berikut.

\begin{tabular}{|c|c|c|c|}
\hline No. & $\begin{array}{c}\text { DP yang } \\
\text { Diperbandingkan }\end{array}$ & $\begin{array}{c}\text { Persentase } \\
\text { Perbedaan }\end{array}$ & $\begin{array}{c}\text { Tingkat Kekerabatan } \\
\text { Bahasa }\end{array}$ \\
\hline 1. & $15-87$ & $49,75 \%$ & Perbedaan Subdialek \\
\hline 2. & $15-88$ & $66,25 \%$ & Perbedaan Dialek \\
\hline 3. & $87-88$ & $67,50 \%$ & Perbedaan Dialek \\
\hline
\end{tabular}

\section{Keterangan:}

DP 87: Lubuk Hiju

DP 88 : Guci

DP 15 : Bulik

Dari data perhitungan dialektometri di atas, dapat disimpulkan bahwa bahasa-bahasa daerah di Kabupaten Lamandau memiliki 
hubungan kekerabatan yang dekat, yakni satu bahasa hanya beda dialek dan subdialek saja. Hal ini dapat dilihat pada persentase pada rentang $49,75 \%--$ $67,50 \%$. Satu bahasa yang dituturkan itu adalah bahasa Tomuan. Hampir tidak terdapat kantong atau enclave yang menggunakan bahasa berbeda.

Sementara itu, hasil perhitungan secara leksikostatistik untuk mendapatkan kategori kekerabatan bahasa-bahasa tersebut dapat dilihat sebagai berikut.

\subsection{Perhitungan Secara leksikostatistik}

\begin{tabular}{|c|c|r|l|}
\hline \multicolumn{4}{|c|}{ PERHITUNGAN LEKSIKOSTATISTIK } \\
\hline DAERAH PENGAMATAN & JUMLAH & $\begin{array}{c}\text { PERSENTASE } \\
\text { KATA } \\
\text { KERABAT }\end{array}$ & $\begin{array}{c}\text { TINGKAT } \\
\text { KEKERABATAN }\end{array}$ \\
\hline & 160 & $80 \%$ & KELUARGA (FAMILY) \\
\hline $15-87$ & 157 & $78,5 \%$ & KELUARGA (FAMILY) \\
\hline $15-88$ & 152 & $76 \%$ & KELUARGA (FAMILY) \\
\hline $87-88$ & & &
\end{tabular}

\section{Keterangan:}

Status Kekerabatan:

$\begin{array}{ll}\text { DP 15-DP 87 } & \text { : Keluarga } \\ \text { DP 15-DP 88 } & \text { : Keluarga } \\ \text { DP 87-DP 88 } & \text { : Keluarga }\end{array}$

Keterangan DP:

$\begin{array}{ll}87 & \text { : Lubuk Hiju/Bahasa Tomuan } \\ 88 & : \text { Guci/Bahasa Tomuan } \\ 15 & : \text { Bulik/Bahasa Tomuan }\end{array}$

Seperti yang terlihat pada tabel di atas, bahasa Tomuan memiliki turunan dialek dan subdialek. Variasi dialeknya pun tidak begitu jauh rentangnya. Hal ini dikarenakan pewarisan kosa kata yang digunakan tidak begitu jauh berbeda.

\subsection{Pohon Kekerabatan Bahasa- \\ Bahasa di Wilayah Kabupaten \\ Lamandau}

Seperti dipaparkan sebelumnya, ketiga bahasa yang diteliti merupakan bahasa-bahasa yang dituturkan di dua kecamatan yang berbeda. Untuk 
mendapatkan kategori kekerabatan ketiga bahasa tersebut dengan bahasa Tomuan, dilakukan perhitungan leksikostatistik, sehingga diperoleh diagram pohon kekerabatannya seperti dalam diagram berikut.

\section{Diagram 1.}

Pohon Kekerabatan Bahasa-Bahasa Di Kabupaten Lamandau

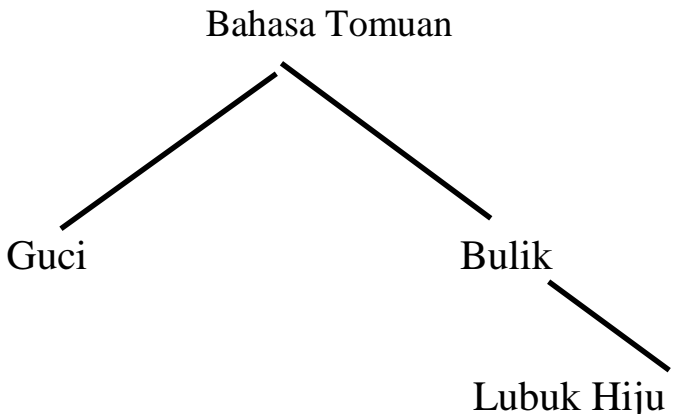

Seperti yang terlihat pada diagram tersebut, diketahui bahwa antara bahasa Bulik, bahasa Guci, dan bahasa Lubuk Hiju terdapat hubungan kekerabatan pada tingkat keluarga bahasa, ketiga bahasa ini memiliki moyang bahasa yang sama, yang disebut Protobahasa Tomuan. Selanjutnya, bahasa Bulik dengan bahasa Lubuk Hiju memiliki hubungan yang lebih dekat daripada hubungan masing-masing kedua bahasa itu dengan bahasa Guci, sehingga dapat dikatakan bahwa bahasa yang digunakan di daerah Bulik dengan bahasa di daerah Lubuk
Hiju berasal dari satu subkeluarga bahasa.

\section{Penutup}

\subsection{Simpulan}

Penelitian variasi bahasa-bahasa di Kecamatan Bulik dan Menthobi Raya, Kabupaten Lamandau merupakan langkah awal untuk mendapatkan gambaran secara keseluruhan tentang situasi kebahasaan di wilayah Kabupaten Lamandau. Penelitian yang dilakukan Pusat Bahasa (2008) telah mendapatkan satu bahasa dengan satu variasi dialek di Kecamatan Bulik, yakni Bahasa Dayak Tamuan Dialek Bulik (DP 15).

Dari hasil perhitungan leksikostatistik dan dialektometri yang digunakan dalam penelitian ini, ditemukan adanya satu variasi dialek dan satu variasi subdialek baru yang digunakan di wilayah Kabupaten Lamandau. Variasi dialek dan satu subdialek ini meliputi wilayah tutur dari Kecamatan Menthobi Raya hingga Kecamatan Bulik. Dengan demikian, bahasa yang terdapat di wilayah Kabupaten Lamandau ditemukan satu bahasa, yaitu bahasa Dayak Tomuan dengan variasi dialek-dialek, yakni dialek Bulik (DP 15), dengan subdialek 
Lubuk Hiju (DP 87) dan dialek Guci (DP 88).

\subsection{Saran}

Sulitnya akses transportasi untuk menjangkau wilayah-wilayah hulu dan perbatasan menjadi salah satu kendala pelaksanaan penelitian. Wilayahwilayah yang kemungkinan belum teridentifikasi pada dasarnya merupakan daerah yang membutuhkan ketersediaan alokasi dana dan prasarana yang memadai. Penelitian-penelitian yang akan datang hendaknya mempertimbangkan jarak dan fasilitas untuk menjangkau daerah-daerah tersebut agar dapat ditemukan kemungkinan adanya isolek lainnya, yakni keberadaan bahasa atau dialek/subdialek. Dengan demikian, hasil penelitian selanjutnya diharapkan lebih kaya akan keberagaman isolek yang masih banyak belum teridentifikasi.

Sinergi dengan pemerintah daerah setempat sangat dibutuhkan mengingat kepentingan pemetaan bahasa-bahasa di Indonesia merupakan langkah strategis untuk memetakan secara konkret jumlah dan situasi bahasa di wilayah provinsi ini. Hasil dari penelitian ini diharapkan dapat memberikan gambaran situasi kebahasaan dan menginventarisasi kekayaan bahasa dan budayanya, sehingga dapat ditentukan skala prioritas untuk melestarikan dan melakukan upaya-upaya penyelamatan bahasa-bahasa yang sudah punah, terancam punah, maupun yang kritis. Dengan demikian, upaya ini akan meminimalisasi laju kepunahan bahasabahasa daerah di Indonesia, baik yang belum maupun sudah teridentikasi.

\section{Daftar Pustaka}

Bynon, Theodora. (1977). Historical Linguistic. Cambridge: Cambridge University Press.

Hudson, Alfred. B. (1967). Barito Isolects of Borneo: A Classification Based on Comparative Reconstruction and Lexicostatistics. Ann Arbor, Michigan: University Microfilm International.

Kridalaksana, Harimurti. (1984). Kamus Lingustik. Gramedia Pustaka Utama.

Mahsun. (1995). Dialektologi Diakronis: Sebuah Pengantar. Yogyakarta: Gadjah Mada University Press.

Mahsun. (2006). Linguistik Historis Komparatif. Yogyakarta: Gama Media.

Ngabut, Yus C. dkk. (1995). Dialek Bahasa Daerah di Kabupaten Barito Selatan. Jakarta: Pusat 
Pembinaan dan Pengembangan Bahasa.

Poerwadi, Petrus dkk. (1993). "Perbandingan Bahasa-Bahasa di Kalimantan Tengah: Studi Pengelompokan Bahasa; Laporan Penelitian. Palangka Raya: Balai Penelitian Universitas Palangka Raya.

Pusat Bahasa. (2008). Peta BahasaBahasa di Indonesia. Jakarta: Tim Penelitian Kekerabatan Bahasabahasa di Indonesia

Samarin, William, J. (1988). Ilmu Bahasa Lapangan. Yogyakarta: Kanisius

Sudaryanto. (1986). Metode Linguistik. Yogyakarta: Gajah Mada University Press.

www.lamandaukab.go.id. Diakses tanggal 23 Mei 2014.

www.oncik.blogspot.com/2012/07/daya k-tomun.html. Diakses tanggal 23 Mei 2014. 